\title{
Nigella Sativa (Black Seeds) Oil Adjuvant Therapy decrease on SGOT activity in Patients at Risk of Metabolic Syndrome receiving Standard Therapy
}

\author{
Endang Darmawan,1 Akrom*1,2, Desi Reski Fajar1* \\ 1. Faculty of Pharmacy, Universitas Ahmad Dahlan Yogyakarta; \\ 2. Center of Drug Information and Research, Universitas Ahmad Dahlan Yogyakarta \\ Email: eddarmawan@gmail.com; *corespondenceauthor:akrom@pharm.uad.ac.id
}

\begin{abstract}
Metabolic Syndrome (MS) may be characterized with obesity and insulin resistance. In obesity, the increased accumulation of fat in the circulation and tissues will lead to Reactive Oxygen Species (ROS), followed by oxidative stress. Nonalcoholic Fatty Liver Disease (NAFLD), the accumulation of excess free fat in the form of triglycerides caused by lipolysis due to insulin resistance, can cause inflammation and liver cells damage characterized by increased serum glutamic oxaloacetic transaminase (SGOT) and serum glutamic pyruvic transaminase (SGPT). Nigella Sativa (Black Seed) oil is known to be efficacious as an antioxidant that can improve hepatic function. This study uses a cross over design to determine the effect of black seed oil with a dose of $1.5 \mathrm{ml} /$ day and $3 \mathrm{ml} /$ day on SGOT and SGPT activities in patients with SM. A total of $62 \mathrm{SM}$ patients were divided into two groups which received $1.5 \mathrm{ml} /$ day and $3 \mathrm{ml} / \mathrm{day}$ respectively for 20 days, and after 7 day washout, the doses were reversed. Measurements were performed on the 21 st and 49th days. The results showed a significant difference in SGOT activity decrease in patients receiving $1.5 \mathrm{ml} /$ day compared with those receiving $3 \mathrm{ml} / \mathrm{day}$. However, in terms of SGPT, there was no significant difference between the two treatment groups.
\end{abstract}

Keywords: Metabolic syndrome, black seed oil, fatty liver, SGOT and SGPT

\section{INTRODUCTIO} $\mathrm{N}$

Metabolic syndrome (MS) is a metabolic disorder in the body caused by risk factors such as obesity, dyslipidemia, hypertension, or insulin resistance (Matsuzawa, 2010). SM in Indonesia is one of the major public health issues. SM incidence rate in Indonesia reached $23 \%$, with $26.6 \%$ in women and $18.3 \%$ in men of productive age based on Basic Health Research (Riset Kesehatan Dasar, or RISKESDAS) (Kemenkes RI, 2013). SM is closely associated with regenerative diseases incidence, one of which is Nonalcoholic Fatty Liver Disease (NAFLD). Approximately $90 \%$ of NAFLD patients meets one of MS criteria and approximately $33 \%$ meets three or more of the criteria (Marzio et al., 2014). Research conducted by Nadila et al., in 2015 mentions that of 30 MS patients who came for treatment in Internal Medicine Clinic of Dr. M. Jamil General Hospital in Padang, 20 patients (67\%) were diagnosed with NAFLD.

According to the World Gastroenterology Organization (WGO) in 2012, fatty liver disease (FLD) is a condition in which excess fat accumulation in the form of triglycerides affects $5 \%$ of hepatocytes in the liver. In some FLD patients, hepatocyte cell damage was detected with an inflammatory response to fatty deposits in the liver (Nadya, 2015). The presence of excessive fat accumulation in the liver will cause fatty liver which then causes inflammation and damage to hepatic cells. This is caused by the accumulation of fat, or obesity, in liver cells and insulin resistance. In the latter case, adipose tissue is no longer able to cope with excess fat levels, causing lipolysis that produces free fatty acid (FFA) in excess amount, which will be transported by the portal vein to the liver. The accumulation in the liver will lead to mitochondrial dysfunction, increased proinflammatory cytokines, oxidative stress leading to increased liver cell sensitivity to injury, and liver cells inflammation and necrosis (Lesmana, 2009). As many as
$15-50 \%$ of FLD cases will develop into fibrosis and $25 \%$ progress to nonalcoholic steatohepatitis (NASH) with $10 \%$ mortality rate (Sears, 2012). Damage to liver cells in NAFLD can be seen from the increased levels of SGOT and SGPT, where the higher the increase in transaminase or aminotransferase enzymes, the more severe the damage level of liver cells (Cahyono, 2009).

The provision of additional therapy (adjuvant therapy) in addition to standard therapy is expected to reduce hepatic damage due to dyslipidemia which commonly occurs in patients with metabolic syndrome. Black seed oil, which contains thymoquinone, has been shown to have antioxidant activity and anti-dyslipidemia in vivo, and has been proven safe in healthy volunteers (Akrom, 2016; Najma et al., 2001). Akrom (2013) states that the provision of black seed oil has been proven to increase glutathione S-transferase (GST) anti-oxidative enzyme and the number of Treg in Sprague Dawley rats induced with Dimethylbenzathrene (DMBA) so as to inhibit the inflammatory reaction that is excessive and remain safe for liver or kidney function. The effect of black seed oil adjuvant therapy on SGOT and SGPT activities in patients with metabolic syndrome with standard therapy is not yet known, and therefore this study is aimed at identifying the effect.

\section{EXPERIMENTAL DETAILS}

The study uses cross over design with a total of 66 patients with metabolic syndrome. However, during the course of the study, four patients were excluded because they experienced side effects such as nausea, vomiting, gastritis, increased blood pressure and decreased renal function. This research was conducted at Puskesmas Jetis I of Bantul Regency, Yogyakarta from August 2016 until March 2017. This clinical trial protocol has been reviewed and validated by health research ethics committee of Medical Faculty, Universitas Muhammadiyah Yogyakarta. 
Prospective subjects who meet the inclusion criteria were gathered together to receive explanation of the research objectives and benefits for the public and volunteers. Those who were willing to participate in the research then received a further explanation of the consequences as volunteers and rewards to be gained. Prospective subjects who were voluntarily and consciously willing to become research subjects were then asked to fill out an informed consent. The subjects who have met the selection requirements and filled the informed consent then, in a simple randomization, were divided into two treatment groups, with each group consisting of 31 volunteers. The randomization result codes were kept by the officer.

Black seed oil is packaged in soft capsule, each containing $0.5 \mathrm{ml}$. In phase $\mathrm{I}$, the treatment group I received $1.5 \mathrm{ml} /$ day $(1 \times 3$ soft capsule $)$ dose while the treatment group II received $3 \mathrm{ml} /$ day $(2 \times 3 \mathrm{soft}$ capsule) for 20 days. On the 12 th day, blood sampling was performed to examine the SGOT and SGPT activities. After a 7-day wash out, on the 28th day, phase II started with the doses given in reverse, where the treatment group I received 3 $\mathrm{ml} /$ day while the treatment group II received $1.5 \mathrm{ml} /$ day for the next 20 days. SGOT and SGPT levels in phase II were measured on the 49th day.

Demographic data, disease diagnosis, medical history, and duration of illness were obtained from medical records completed with interviews guided by questionnaires conducted by trained personnel. SGOT and SGPT activity was measured with spectrophotometer method. $2 \mathrm{ml}$ of blood was taken by trained health analysts from the median cubital vein using the protocol that has been reviewed and approved by health research ethics committee of Medical Faculty, Universitas Muhammadiyah Yogyakarta. The analysis was conducted at Puskesmas Jetis I, Bantul which also serves as the research site.

Data on subject demographic and clinical characteristics are presented descriptively. SGOT and SGPT activity data were obtained by inter-group average test on one take with one-way ANOVA or unpaired T-test. The difference of SGOT and SGPT activity in one group between measurements (blood taking) was calculated by paired $\mathrm{T}$ test. All tests were performed with a $95 \%$ significance level.

\section{RESULTS AND DISCUSSION}

\section{Demographic and clinical characteristics}

The characteristics of the study subjects are shown in Table 1 including sex, age, marital status, education, and employment. It can be seen that by sex, women tend to suffer more from metabolic syndrome than men, with 26 compared to 7 patients in each treatment group. By age, 56-64 years are more likely to suffer from metabolic syndrome compared with younger age groups and the oldest age group (>64 years). This is in line with research conducted by Nathania et al., 2015 stating that FLD in patients with hypertension (one of the metabolic syndrome characteristics) is mostly suffered by women aged 51-60 years.

Based on education, subjects with low levels of education- from non-schoolers to primary school- were more likely to develop metabolic syndrome with 33 patients, while subjects with juniorhigh school education were 24 patients, and subjects with a Diploma and Bachelor degree were 9 patients. Based on occupation, 16 patients were those who were unemployed while those who work as civil servants accounted for the lowest with 3 patients. This is in line with research conducted by Krisnawati et al., 2012 suggesting that the prevalence of metabolic syndrome in women is higher than that in men, but both men and women have the same potential for developing metabolic syndrome. It is also said that metabolic syndrome risk corresponds to increasing age, because organs ability to function has been increasingly weakened, including damage to the pancreas in producing insulin that triggers other characteristics of metabolic syndrome. Similarly, education levels and occupations are also associated with metabolic syndrome risk. These data indicate that the treatment group I and II have significance values of $p>0.05$, which means that there is no significant difference in the characteristics between the two groups.

Table I. Demographic Characteristics of Research Subjects

\begin{tabular}{|c|c|c|c|}
\hline \multirow[t]{2}{*}{ Patient characteristics } & \multicolumn{2}{|c|}{ Group } & \multirow[t]{2}{*}{$\mathbf{P}$} \\
\hline & $\begin{array}{l}\text { Treatment I } \\
(\mathbf{N}=\mathbf{3 3})\end{array}$ & $\begin{array}{c}\text { Treatment II } \\
(\mathbf{N}=\mathbf{3 3})\end{array}$ & \\
\hline Gender & & & 0.618 \\
\hline Man & $7(21.2 \%)$ & $7(21.2 \%)$ & \\
\hline Women & $26(78.8 \%)$ & $26(78.8 \%)$ & \\
\hline Age & & & .953 \\
\hline $36-45$ years old & $5(15.2 \%)$ & $4(12.1 \%)$ & \\
\hline $46-55$ years old & $12(36.4 \%)$ & $11(33.3 \%)$ & \\
\hline $56-65$ years & $13(39.4 \%)$ & $14(42.4 \%)$ & \\
\hline$>65$ years old & $3(9,1)$ & $4(12.1 \%)$ & \\
\hline Marital status & & & 0.314 \\
\hline Married & $32(97.0 \%)$ & $33(100 \%)$ & \\
\hline Single & $1(3.0 \%)$ & $0(0 \%)$ & \\
\hline Education & & & 0.176 \\
\hline No school-primary school & $17(51.5 \%)$ & $16(48.5 \%)$ & \\
\hline Junior-senior high school & $14(42.4 \%)$ & $10(30.3 \%)$ & \\
\hline Diploma-Master & $2(6.1 \%)$ & $7(21.2 \%)$ & \\
\hline
\end{tabular}




\begin{tabular}{|c|c|c|c|}
\hline Occupation & & & 0.122 \\
\hline Civil servants & $0(0 \%)$ & $3(9.1 \%)$ & \\
\hline Entrepreneur & $3(9.1 \%)$ & $5(15.2 \%)$ & \\
\hline Farmers & $3(9.1 \%)$ & $5(15.2 \%)$ & \\
\hline Private sector & $2(6.1 \%)$ & $2(6.1 \%)$ & \\
\hline Labor & $7(21.2 \%)$ & $4(12.1 \%$ & \\
\hline Fisherman & $0(0 \%)$ & $4(12.1 \%)$ & \\
\hline Unemployed & $11(33.3 \%)$ & $5(15.2 \%)$ & \\
\hline Others & $7(21.2 \%)$ & $5(15.2 \%)$ & \\
\hline
\end{tabular}

The characteristics of the metabolic syndrome patients are shown in Table II based on metabolic syndrome description, illness duration, and drug routinely taken by the patients. A person is diagnosed with metabolic syndrome disease when they show 2 out of $4 \mathrm{MS}$ criteria according to National Cholesterol Education Program (NCEP III). Of the 66 total study subjects, the highest numbers were patients with diabetes mellitus and hypertension with 16 patients divided into two treatment groups. Subjects consume routine drugs based on their MS risk and they also routinely check their condition in the Puskesmas. Illness duration from MS in this research subjects is 1-3 years. The table also shows the significance values of $p>0.05$, which means that there is no significant difference in the characteristics between the two groups.

Table II. Clinical Characteristics of Metabolic Syndrome Outpatient in Jetis Public Health Center (PHC), Bantul

\begin{tabular}{|c|c|c|c|}
\hline \multirow[t]{2}{*}{ MS Characteristics } & \multicolumn{2}{|c|}{ Group } & \multirow[t]{2}{*}{$\mathbf{P}$} \\
\hline & $\begin{array}{l}\text { Treatment I } \\
\qquad(\mathbf{N}=\mathbf{3 3})\end{array}$ & $\begin{array}{l}\text { Treatment II } \\
\qquad(\mathbf{N}=\mathbf{3 3})\end{array}$ & \\
\hline Description SM & & & 0.697 \\
\hline DM + Hypertension & $8(24.2 \%)$ & $8(24.2 \%)$ & \\
\hline \multicolumn{4}{|l|}{ DM + Hypertension + Hypertriglyceridemia } \\
\hline $\mathrm{DM}$ & $4(12.1 \%)$ & $8(24.2 \%)$ & \\
\hline DM + Hypercholesterolemia & $5(15.2 \%)$ & $5(15.2 \%)$ & \\
\hline Hypertension & $1(3.0 \%)$ & $1(3.0 \%)$ & \\
\hline DM + Hypertension + Hypercholesterol & $1(3.0 \%)$ & $0(0 \%)$ & \\
\hline \multicolumn{4}{|l|}{$\mathrm{DM}+$ Hypertension + Obesity } \\
\hline DM + Hypertension + Hypertriglycerides + & $3(9.1 \%)$ & $2(6.1 \%)$ & \\
\hline Obesity & $2(6.1 \%)$ & $0(0 \%)$ & \\
\hline \multicolumn{4}{|l|}{$\mathrm{DM}+$ Obesity } \\
\hline \multicolumn{4}{|l|}{ DM + Hypertriglycerides } \\
\hline $\mathrm{DM}+$ Hypertension + Hiperdislipidemia & $0(0 \%)$ & $2(6.1 \%)$ & \\
\hline DM + Hiperdislipidemia & $0(0 \%)$ & $1(3.0 \%)$ & \\
\hline \multirow[t]{4}{*}{ Hypertriglyceride } & $3(9.1 \%)$ & $3(9.1 \%)$ & \\
\hline & $3(9.1 \%)$ & $2(6.1 \%)$ & \\
\hline & $2(6.1 \%)$ & $1(3.0 \%)$ & \\
\hline & $1(3.0 \%)$ & $0(0 \%)$ & \\
\hline \multicolumn{3}{|l|}{ Illness Duration } & \multirow{6}{*}{0.675} \\
\hline$<1$ year & $8(24.2 \%)$ & $5(15.2 \%)$ & \\
\hline $1-3$ years & $11(33.3 \%)$ & $9(27.3 \%)$ & \\
\hline$>3-6$ years & $6(18.2 \%)$ & $7(21.2 \%)$ & \\
\hline$>6-9$ years & $2(6.1 \%)$ & $5(15.2 \%)$ & \\
\hline$>9$ years & $6(18.2 \%$ & $7(21.2 \%)$ & \\
\hline \multicolumn{3}{|l|}{ Routine Medication } & 0.652 \\
\hline \multicolumn{4}{|l|}{1 drug $\mathrm{DM}+1$ hypertension medication } \\
\hline 2 drugs DM +1 hypertension medication & $7(21.2 \%)$ & $10(30.3 \%)$ & \\
\hline \multicolumn{4}{|l|}{1 drug $\mathrm{DM}+2$ hypertensive medication } \\
\hline $1 \mathrm{DM}+2$ drug dyslipidemia & $6(18.2 \%)$ & $6(18.2 \%)$ & \\
\hline \multicolumn{4}{|l|}{$1 \mathrm{DM}$ drug } \\
\hline 1 hypertension medication & $1(3.0 \%)$ & $1(3.0 \%)$ & \\
\hline 1 drug dyslipidemia & $1(3.0 \%)$ & $0(0.0 \%)$ & \\
\hline
\end{tabular}




2 DM medications
2 drugs DM +2 hypertension medication
1 drug DM +1 hypertensive drug +1 drug
dyslipidemia
2 drugs DM +1 drug dyslipidemia
3 DM medications

2 DM medications

$9(27.3 \%)$

$1(3.0 \%)$

$1(3.0 \%)$

$5(15.2 \%)$

$1(3.0 \%)$

$0(0.0 \%)$

$1(3.0 \%)$

$0(0.0 \%)$
$5(15.2 \%)$

$0(0.0 \%)$

$0(0.0 \%)$

$5(15.2 \%)$

$1(3.0 \%)$

$3(9.1 \%)$

$1(3.0 \%)$

$1(3.0 \%)$

Before the study subjects were given treatment (day 0), SGOT and SGPT levels were measured, and the results are shown in Table III..

Table III. Pre-treatment clinical condition (SGOT and SGPT levels, blood preesure and BMI) of Metabolic Syndrome Risk Patients receiving standard therapy in PHC Jetis 1

\begin{tabular}{|l|l|l|l|}
\hline \multicolumn{2}{|l|}{ Clinical Condition } & Average U/L & \multicolumn{1}{c|}{ p value } \\
\hline SGOT ( U/L) & Treatment I $(\mathrm{n}=33)$ & $23,64 \pm 12,10$ & 0,696 \\
& Treatment II $(\mathrm{n}=33)$ & $22,64 \pm 8,25$ & \\
\hline SGPT (U/L) & Treatment I $(\mathrm{n}=33)$ & $22,09 \pm 11,53$ & 0,945 \\
& Treatment II (n=33) & $22,27 \pm 9,56$ & \\
\hline
\end{tabular}

Table IV. SGOT and SGPT Measurement Results on Day 21 and Day 49 of MS Risk Patients receiving standard and adjunctive therapy (1.5 and $3 \mathrm{ml} /$ day for $2 \times 20$ days).

\begin{tabular}{|c|c|c|c|c|c|}
\hline $\begin{array}{c}\text { Clinical } \\
\text { conditions }\end{array}$ & & $\begin{array}{c}\text { Average } \\
\text { Day } 21\end{array}$ & $\begin{array}{c}P \\
\text { value }\end{array}$ & $\begin{array}{c}\text { Average } \\
\text { Day } 49\end{array}$ & $P$ value \\
\hline SGOT & $\begin{array}{l}\text { Treatment I }(\mathrm{n}=31) \\
\text { Treatment II }(\mathrm{n}=31)\end{array}$ & $\begin{array}{l}23,32(7,21) \\
19,32(5,82) \\
\end{array}$ & 0,019 & $\begin{array}{l}25,87(12,05) \\
20,32(5,33) \\
\end{array}$ & 0,022 \\
\hline SGPT & $\begin{array}{l}\text { Treatment I }(\mathrm{n}=31) \\
\text { Treatment II }(\mathrm{n}=31)\end{array}$ & $\begin{array}{l}20,87(8,045) \\
18,45(6,01)\end{array}$ & 0,185 & $\begin{array}{l}23,61(15,72) \\
21,45(7,80)\end{array}$ & 0,495 \\
\hline
\end{tabular}

Day 0 measurements show that subjects SGOT and SGPT levels were clinically within normal limits and there is no statistically significant difference $(\mathrm{p}>0.05)$. The average of SGOT level in treatment group I and II were 23,64 $\pm 12,10 \mathrm{U} / \mathrm{L}$ and $22,64 \pm 8,25 \mathrm{U} / \mathrm{L}$ respectively, while SGPT were 22,09 $\pm 11,53 \mathrm{U} / \mathrm{L}$ and $22,27 \pm 9,56 \mathrm{U} / \mathrm{L}$ respectively.

\section{SGOT and SGPT Levels after Treatment}

The results of SGOT and SGPT measurements in the first 20 days (conducted on the 21 st day) and the second 20 days (conducted on the 49th day) are shown in Table IV.

Data obtained on Day 21 and 49 measurements were analyzed with unpaired T-test stand the results are presented in Table IV. The table shows that there was a significant difference in SGOT activity between treatment group I and treatment II both on day 21 and day 49 with significance value of $\mathrm{P}<0,05$. Meanwhile, there was no significant difference in SGPT activity between treatment groups on either day 21 or day 49 with $\mathrm{P}>0.05$. The SGOT average day 21 in the treatment group I was $23 \mathrm{U} / \mathrm{L}$, while the average in the treatment group II was $19 \mathrm{U} / \mathrm{L}$. In addition, the SGPT average in the treatment group I was $20 \mathrm{U} / \mathrm{L}$, while the average in the treatment group II was $19 \mathrm{U} / \mathrm{L}$. This indicates that $3 \mathrm{ml} /$ day dose had better SGOT and SGPT activity compared with 1.5 $\mathrm{ml} /$ day within 20 days of administration. In contrast, the SGOT average on day 49 showed no difference in effect between $3 \mathrm{ml} /$ day and $1.5 \mathrm{ml} /$ day doses. The treatment group I has an average value of $26 \mathrm{U} / \mathrm{L}$, while treatment group II has an average value of $20 \mathrm{U} / \mathrm{L}$. This is similar to SGPT activity, where the treatment group I has an average value of $24 \mathrm{U} / \mathrm{L}$ while the treatment group II has an average value of $22 \mathrm{U} / \mathrm{L}$.

The results also illustrate that the SGOT and SGPT activity in the treatment group I show no significant difference between the baseline (day 0 measurement) and the measurements on day 21 and day 49 with significance value of $\mathrm{p}>0.05$. However, in the case of SGPT activity in the treatment group II, there was a significant difference between the baseline and the day 21 measurements $(\mathrm{p}<0.05)$, although day 49 measurements did not differ from baseline with $\mathrm{p}>0.05$. SGOT activity in the treatment group II on day 21 and day 49 measurements was not different with the baseline ( $p>$ $0.05)$.

Increased SGOT and SGPT as an indicator of liver damage can be prevented or corrected with the use of antioxidants (winarsih, 2009). In previous research, it is found that Nigella Sativa contains thymoquinone, a compound that is efficacious as antioxidants. This active compound is the main component of black seed oil which can increase anti-oxidative enzyme glutathione S-transferase and the number of Treg in mice induced with dimethylbenzathrene (DMBA) so as to inhibit the inflammatory reaction (Akrom, 2013). In phase I clinical trials, it is evident that black seed oil is safe for liver function (Oktaviyanti, 2015).

\section{CONCLUSIONS}


It can be concluded that, compared to $1.5 \mathrm{ml} /$ day dose, the effect of $3 \mathrm{ml} /$ day dose of black seed oil administered for 20 days on SGOT activity of metabolic syndrome risk patients receiving standard therapy is higher, although such effect is not clinically meaningful. In addition, both doses do not clinically affect SGPT activity during the treatment

period.

Acknowledgments: The researchers would like to thank all parties who have assisted directly or indirectly in the completion of this research, especially to all volunteers who have been willing to be study subjects and all staff and leaders of Puskesmas Jetis I Bantul, Daerah Istimewa Yogyakarta, who have granted permissions to use the facilities to conduct this research. The researchers ultimately would like to thank Kemenristek Dikti, RI, who have funded this research.

\section{References and Notes}

1. Akrom. 2013. Mekanisme kemoprefentif ekstrak heksan BJH pada tikus SD diinduksi DMBA: kajian antioksidan dan imunomodulator. Disertasi. Program Doktor Ilmu Kedokteran dan kesehatan FK UGM. Yogyakarta

2. Astari, Andam, N., Decroli, E., Yerizel, E., 2015, Gambaran NAFLD pada pasien dengan sindrom metabolik di Poliklinik Penyakit Dalam RSUP Dr. Jamil Padang, Universitas Andalas: Padang, Jurnal Kesehatan Andalas, 4(2).

3. Cahyono, 2009, Hepatitis A, Yogyakarta, Kanisius Yogyakarta

4. Pratt, D.S., 2010, Liver Chemistry and Function Test, In; Feldma, M., Friedma, LS., Brandt, LJ., eds., Scheisenger and Fordtran's Gastrointestinal and Liver Disease, Saunders Elsevier, Philadelphia.

5. Kementrian Kesehatan RI, 2013, Riset Kesehatan Dasar (RISKESDAS 2013), Badan Penelitian dan Penegmbangan Kesehatan RI; Jakarta.

6. Komang, W.J., 2011, Kejadian Sindrom Metabolik Berdasarkan Status Obesitas pada Masyara kat Perkotaan Di Denpasar, Jurusan Gizi Poltekes Denpasar.

7. Krisnawaty B., Hari K.Y., Budi, M., 2012, Perbedaan Gender pada Kejadian Sindrom Metabolik pada Penduduk Perkotaan di Indonesia, Jurnal penelitian, Departemen Epidemiologi Fakultas Kesehatan Masyarakat Universitas Indonesia, Program studi Ilmu Kesehatan dan Kedokteran Kesehatan Universitas Gadjah Mada.

8. Lesmana, et al., 2009, Perlemakan Hati Non-Alkoholik (Non alcoholic Fatty Liver Disease), Buku ajar ilmu penyakit hati, Jakarta: Jaya Abadi.

9. Magfira, N., 2015, Gambaran Demografis Penyakit Perlemakan Hati Non-Alcoholic dengan Diabetes Melitus Tipe II di RSUP Fatmawati Tahun 2013-2014, Skripsi, Fakultas Kedokteran dan Ilmu Kesehatan Universitas Islam Negeri Syarif Hidayatullah; Jakarta.

10. Matsuzawa,Y., 2010, Obesity as an endocrine disease, in: Kopelmen PG., Caterson ID., Diez WH., third edition, Oxford: Blackwell Publishing Limited, page: 200.

11. Marzio, H.D., Dina L., Fenkel, J.M., 2014, Consepts and Treatment Approaches in Nonalcoholic Fatty Liver Disease, Advances in Hepatology.

12. Oktavianti, N., 2015, Gambaran Ekspresi Gen Interferon- $\gamma$ (IFN- $\gamma$ ) dan aktivitas SGOT-SGPT pada Relawan Sehat yang Diberi Minyak Biji Jinten Hitam (MBJH), Tesis, Program Studi Pascasarjana Farmasi, Universitas AhmadDahlan: Yogyakarta

13. Winarsi, H., 2011, Antioksidan Alami dan Radikal Bebas, Kanisius, Yogyakarta.

14. World Gastroenterology Organization, 2012, Non-Alcoholic fatty liver disease and NonAlcoholic Steatohepatitis, USA: World Gastroenterology Organization. 